Southern Methodist University

SMU Scholar

Faculty Journal Articles and Book Chapters

Faculty Scholarship

2010

\title{
(When) Should Family Status Matter in the Criminal Justice System
}

\author{
Jennifer M. Collins \\ Southern Methodist University, Dedman School of Law \\ Ethan J. Leib \\ Fordham University \\ Dan Markel \\ Florida State University College of Law
}

\section{Recommended Citation}

Jennifer M. Collins; Ethan J. Leib; Dan Markel, (When) Should Family Status Matter in the Criminal Justice System, 13 NEW CRIM. L. REV. 151, 175 (2010).

This document is brought to you for free and open access by the Faculty Scholarship at SMU Scholar. It has been accepted for inclusion in Faculty Journal Articles and Book Chapters by an authorized administrator of SMU Scholar. For more information, please visit http://digitalrepository.smu.edu. 


\section{(WHEN) SHOULD FAMILY STATUS MATTER IN THE CRIMINAL JUSTICE SYSTEM? \\ Jennifer M. Collins, ${ }^{\star}$ Ethan J. Leib, ${ }^{\star \star}$ and Dan Marke/ ${ }^{\star \star \star}$}

We would like to begin by thanking Professors Berman, Cahn, and Chin for the time and care with which they have engaged our work and for furnishing us with an opportunity to discuss, clarify, and rethink some of the key claims and concerns associated with our recent book, Privilege or Punish: Criminal Justice and the Challenge of Family Ties. Needless to say, we appreciate their very kind words about our project and its contributions. In this Essay, our focus will be on responding to the interesting criticisms lodged against our book; we hope to do so in a way that is helpful in advancing the conversation about the intersection between criminal justice and family status beyond these pages.

\section{ON THE NATURE OF POLICY ANALYSIS: OUTSIDE THE EMPIRE OF EMPIRICISM?}

Based on the comments of both Professors Jack Chin and Doug Berman, it seems appropriate and necessary for us to say a bit more about the methodology of Privilege or Punish. In particular, we need to highlight and clarify the role of empirical evidence within the overall project pursued in the book.

${ }^{*}$ Professor, Wake Forest University School of Law.

**Visiting Associate Professor of Law, UC-Berkeley; Associate Professor, UC-Hastings College of the Law.

${ }^{* * *}$ D'Alemberte Professor, Florida State University College of Law. We are grateful to Jack Chin and Holly Griffin for comments and conversations on earlier versions.

New Criminal Law Review, Vol. 13, Number I, pps I5I-175. ISSN 1933-4192, electronic ISSN 1933-4206. (C) 2010 by the Regents of the University of California. All rights reserved. Please direct all requests for permission to photocopy or reproduce article content through the University of California Press's Rights and Permissions website, http://www. ucpressjournals.com/reprintInfo.asp. DOI: I0.1525/nclr.20IO.I3.I.I5I. 


\section{A. Professor Berman's "Empirical" Critique}

Professor Berman's critique observes, at the outset, the "extraordinary contribution" our book makes in terms of spotlighting attention on the various ways the criminal justice system's laws impose various burdens or benefits on persons by virtue of their familial status. 'We are relieved to see that acknowledgment - that was our book's explicit focus. Unfortunately, he then chides us for not considering the relationship between family status and "fundamental crime realities," and for not discussing various studies identifying patterns of crime connected to the presence or absence of family ties and/or gender dynamics. ${ }^{2}$ Similarly, Professor Chin notes the contribution the book makes by discovering "a new facet of criminal law that had until now been hiding in plain sight." 3 But his essay encourages us to be clearer about the degree to which empirical conclusions are necessary to reach firm conclusions regarding the book's recommendations. These challenges warrant careful response.

In the Introduction to our book, we specifically noted that many scholars have tried to look at the empirical issues Professor Berman in particular is interested in, especially with respect to what he calls the "relationship of family status, gender dynamics and crime."4 We acknowledged, moreover, the tremendous scholarship cataloguing, among other things, "the devastating impact that the incarceration of relatives can have on the family members left behind."5 Furthermore, to the extent such research yields clear signals, we could not have been more transparent about the need for these effects to be considered as part of an overall evaluation of criminal justice policies. As we wrote, "There is no doubt that many of the criminal

I. Douglas A. Berman, Digging Deeper into, and Thinking Better about, the Interplay of Families and Criminal Justice, 13(I) New Crim. L. Rev. 119 (2010).

2. Id. at 122 ("Privilege or Punish not only fails to engage key sociological and criminogenic realities involving family ties, but it fails even to acknowledge the profound interplay of families ties, gender dynamics, and criminal offending that operate beneath the formal criminal law doctrines they discuss and assail.").

3. Gabriel J. Chin, Mandatory, Contingent and Discretionary Policy Arguments, I3(I) New Crim. L. Rev. 142, 142 (2010).

4. See Dan Markel, Jennifer M. Collins, \& Ethan J. Leib, Privilege or Punish: Criminal Justice and the Challenge of Family Ties, xiv (2009).

5. Id. (citing, e.g., Donald Braman, Doing Time on the Outside (2004); Sandra Enos, Mothering from the Inside: Parenting in a Woman's Prison (2001); Joan Petersilia, When Prisoners Come Home: Parole and Prisoner Reentry (2003)). 
law's policies and practices disadvantage families in many ways-and without attention to this sort of disparate impact on families, policy designers risk tearing our social fabric at the seams."

All that said, we thought we were quite clear that our endeavor had a different objective. Rather than focus on, for example, the effects on offenders, victims, or third parties associated with "facially neutral" criminal justice policies, we emphasized that we would focus our attention, using tools of legal analysis and political theory, on those criminal laws that consciously target defendants for special privileges or burdens on account of their familial status. ${ }^{7}$ Contrary to Professor Berman's claim that this focus on analysis of criminal law was somehow obscured, ${ }^{8}$ we said as much on our book jacket and in our Introduction no less than a handful of times. ${ }^{9}$

6. Id. For example, the collateral consequences to innocent persons in the context of irreplaceable caregivers motivated our proposal for "time-deferred incarceration." See id. at 48-53.

7. In terms of family ties benefits, we examined roughly six areas: evidentiary privileges, exemptions for family members for harboring fugitives, violence within the family, pretrial release, sentencing discounts based on family ties, and prison policies. In terms of family ties burdens, we studied seven areas: omissions liability for failure to rescue, parental responsibility laws, incest, bigamy, adultery, nonpayment of child support, and nonpayment of parental support.

8. See Berman, supra note I, at 122 ("The authors might respond that their goal was only to discuss and assess formal doctrines and not real-world outcomes. If so, they at least should have made this important point clearer in both the title and text.").

9. The suggestion that our subtitle, which uses the words "criminal justice" (and not "criminal law") connotes a dramatically different focus, and that we are somehow being coy or furtive about our focus, seem rather odd. Professor Berman himself can read what he quoted from our book earlier in his review: namely, that we focus on the "panoply of laws expressly drawn to privilege or disadvantage persons based on family status alone," Markel, Collins, \& Leib, supra note 4, at xv. Our Introduction to the book, moreover, is littered with statements regarding our focus of inquiry. See, e.g., id. at xiii (noting that we are interested in asking descriptive and normative questions about "the facial treatment of family status" within the criminal law); id. at xv ("[W]e have chosen here to focus on explicit legislative or judicial choices to privilege or burden individuals with family relationships."); id. ("We believe policymakers need to reflect upon the explicit choices they have made, choices that have been insufficiently analyzed in a synthetic manner by academics before this project. Once we have a framework for analyzing the explicit family ties benefits and burdens, one might be able to apply elements of that framework to the unstated and more obscured informal benefits and burdens. But to develop that framework in the first instance, we focus on facial benefits and burdens."); id. at xv ("Scholars have been successful in analyzing the effects of certain criminal justice policies and practices on the family. But most scholars have not recognized the panoply of laws expressly drawn to privilege or disadvantage persons based on family status alone. Some have addressed singular instances of the larger phenomenon 
Professor Berman might then say that, even if such a focus on criminal laws rather than criminal justice outcomes were better articulated, it doesn't excuse the failure to undertake a more wide-ranging excursion into the empirical findings of criminologists who have examined the "relationship of family status, gender dynamics, and crime." Our response here has several layers.

First, when we discovered relevant empirical evidence about the efficacy associated with the specific laws and policies we study, ${ }^{10}$ we cited it and addressed it." In various instances, such as the discussion of evidentiary privileges, our conclusions were tempered and more tentative in light of concerns raised by extant or possible empirical findings. ${ }^{12}$ Unsurprisingly, this sensitivity to the existing evidence and the possibility of confounding empirical results is noted by Professor Chin in his essay.

Second, it is important to note that, for many of the specific areas we studied, we saw no directly relevant empirical research. To illustrate, consider the following: Do states granting exemptions to family members who harbor fugitives have higher crime rates than states that do not? Do states with incest, adultery, parental supervision, or parental support laws have lower rates of crime than those states that don't? Have states that dropped family ties burdens experienced a surge in crime or an increase in quality of family life? Do those states without "family ties benefits" to defendants have any markers suggesting stronger or weaker family life? Lower or higher crime rates? Do states with more immunities for spouses get more or less accurate information in criminal justice proceedings? Do immunities lead to what Professor Berman calls "healthier" or more "wholesome" families? We could go on.

we chart, but we are the first to offer a synthetic approach. It seems important and necessary to pause and think through how and why our laws intentionally target family status and how the underlying goals of such a choice might better be served in some cases. This book clears that ground."). Our book jacket's summary of the book also makes clear that we are focused on "the panoply of laws (whether statutory or common law-based) expressly drawn to privilege or disadvantage persons based on family status alone."

Io. See supra note 7 .

II. E.g., Markel, Collins, \& Leib, supra note 4, at 128-35 (discussing empirical studies associated with polygamy); id. at $189 \mathrm{n} .77$ (discussing Bedard \& Helland's study showing that the farther away a prison was located from a female defendant's family, the greater the decrease in crime).

12. E.g., id. at 140-44 (discussing deterrence effects associated with criminal laws related to deadbeat parents); id. at 40 (discussing the possibility that evidentiary privileges protect the criminal trial from being polluted by perjuring family members). 
Importantly, and disappointingly, nothing Professor Berman alludes to provides an answer to these specific questions. This should not come as a surprise. After all, most scholars, whether in law schools or criminology departments, have not studied the effects of most of the laws that were the focus of our book. Indeed, as Professor Chin avers, most of these laws were "hiding in plain sight" - and thus obscured from systematic and synthetic legal analysis, which the book undertakes, ${ }^{13}$ and empirical study as well, which the book does not. Thus, for the most part, as nonspecialists in empirical studies, we were left in the position of identifying and encouraging fruirful avenues for further empirical research that would test our hypotheses about the effects associated with these various family ties benefits or burdens. Although those tests will have to await future study, we still believe we have offered useful observations and normative analysis that could help policymakers process such empirical evidence if it becomes available.

What's more, Professor Berman's scholarly citations, which reflect the predictable gender patterns associated with criminal incidence, are all red herrings as far as we can tell: he doesn't identify how any one of them focuses on outcomes related to criminal laws that are creating benefits or burdens based on legal family status. ${ }^{14}$ Instead he alludes to research undertaken by criminologists that are part of a "social control" theory meant to explain what factors reduce crime more generally. But these tactics fail to directly intersect with the specific objects of our study. For example, Professor Berman quotes an article to the effect that

A large body of research in this area reveals many family variables significantly related to crime. Most notably, juveniles commit fewer criminal acts when they are emotionally attached to parents, exposed to consistent parental supervision, reinforced when they engage in prosocial behavior, and exposed to consistent, fair, and nonphysical parental discipline. ${ }^{15}$

13. Importantly, we don't claim that each of the family ties burdens or benefits was obscured from prior analysis; it would be silly to suggest that incest or evidentiary privileges for family members were hitherto unexplored. What we hope was innovative about our efforts was trying to see what connections and critiques can be made by looking at the various benefits and burdens in tandem and juxtaposition.

14. See generally Berman, supra note $\mathrm{I}$.

15. Id. at I2I (quoting Carter Hay et al., The Impact of Community Disadvantage on the Relationship between the Family and Juvenile Crime, 43 J. Res. Crime \& Delinq. 236, 327-29 (2006). 
Assuming arguendo this is all true, nòne of it calls into question a single prescription of ours. After all, we repeatedly acknowledged the role of families in reducing criminogenesis and in socializing cirizens, among other important tasks. ${ }^{16}$ We say nothing in our book that casts doubt on the wisdom of subsidizing family interests through civil institutions of distributive justice that would foster emotional attachment to parents; nothing that denies the benefits of encouraging juveniles to "engage in prosocial behavior"; and nothing in derogation of "consistent, fair, and nonphysical parental discipline." Indeed, we actually express hostility to criminal law defenses that redound to parents when they physically assault their children in the name of "parental discipline." 17

To challenge any of our particular policy judgments on empirical grounds, Professor Berman would need some evidence that indicates, or even suggests, where we were off the mark. But Professor Berman not only fails to adduce empirical evidence to challenge our prescriptions, he also never challenges the prescriptive conclusions we draw with respect to a single instance of a burden or a benefit. Put simply, nothing in his essay gets to the particulars and suggests that the way we would prefer to alter a particular law has been shown to be antithetical to good "criminal justice outcomes."

Indeed, as a prescriptive matter, all Professor Berman asseverates is the following:

As a matter of real-world criminal justice outcomes, it would seem that for all persons-and perhaps especially for women-healthy, wholesome, and happy family ties are likely to advance the authors' asserted normative commitments, while unhealthy, unwholesome, and unhappy family ties are likely to undermine these normative commitments. If this is true, then it is misguided for the authors to call for a general presumption against both family status benefits and burdens in the criminal justice system. Preferable would be a general presumption in favor of benefits for healthy, wholesome and happy family ties and a general presumption in favor of burdens for unhealthy, unwholesome and unhappy family ties. ${ }^{18}$

I6. See, e.g., Markel, Collins, \& Leib, supra note 4, at 25 ("All things being equal, we do not think states can succeed without being attentive to the way in which selves are constructed through families-and we agree that if states are going to feed on the capacirygenerating benefits families confer, it is not inappropriate for families to demand some subsidization in return. Families may be labors of love, but they are full of real undercompensated labor all the same."); see also id. at 53-56 (emphasizing the role family members and loved ones can play in facilitating successful prisoner reentry).

17. See Markel, Collins, \& Leib, supra note 4 , at $45-46$.

18. Berman, supra note 1 , at 156 (emphasis on "general . . system" added). 
This claim is intriguing but entirely undeveloped. Professor Berman doesn't specify a single example of a criminal justice policy that would constitute a burden that should be placed on "unhealthy, unwholesome, and unhappy family ties." Nor does he identify one benefit that should be enjoyed by defendants in order to cultivate "healthy, wholesome, and happy family ties." We also note some discomfort with Professor Berman's use of the word "wholesome" here. Who gets to decide whether any particular family grouping is "wholesome?" 19

Interestingly, Professor Berman's preference to support "healthy" family ties and burden "unhealthy" ones is nominally juxtaposed against our "general presumption" against the use of family status benefits and burdens. Although Professor Berman's review faults us for not having "dug deeper" into the study of family ties, ${ }^{20}$ we wish he had read the book's description of the "general presumption" more attentively. As the book makes clear in the Introduction, develops in chapters 2 and 5, and implements in chapters 3 and 6, the general presumption we craft is intended to operate as nothing more than a speed bump that raises several kinds of reasons to be cautious about the use of family status. Specifically, the speed bump forces the policymaker to subject the use of family status in a particular context to something akin to equal protection analysis regarding suspect classifications. ${ }^{21}$ The presumption forces the beginning of the inquiry, not the end of it.

Thus, importantly, we did not say that the law should jettison all manifestations of family status in the criminal law. ${ }^{22}$ Rather, once we see that a criminal law uses family status, we argue that some scrutiny is warranted to ensure that the various benefits or burdens are justifiable vis-à-vis the core commitments of an effective and fair criminal law that prioritizes the security, liberty, and equality of citizens.

19. Moreover, Professor Berman fails to indicate which of the burdens and benefits we've studied would actually help or hinder any families, wholesome or otherwise.

20. See id., "Digging Deeper."

2I. As we explain, we want policymakers, when tempted to use family status as the basis for a benefit or burden, to make sure there is an important or compelling objective and that the means adopted to pursue that objective are "narrowly tailored" to achieve that objective, looking especially to see whether alternative measures might be effective, such as a focus on function rather than status. Markel, Collins, \& Leib, supra note 4 , at xvii.

22. See, e.g., id. at I03 (arguing that we should preserve status-based duties to rescue for parents or spouses as a strong presumption that is overcome when parents terminate rights or when spouses divorce). 
As we summarize in our Coda, some of the family ties benefits or burdens should be eliminated, while others can be plausibly justified once they are re-tailored in a manner that is less likely to raise concerns that the benefits or burdens are operating in ways that denigrate people living outside the traditional paradigm of heterosexual and repronormative families. As we noted above, Professor Berman doesn't challenge the result or reasoning of any of the applications of the general presumption.

\section{B. Professor Chin's Plea for Clarity Regarding Empirical Values}

The preceding discussion vis-à-vis Professor Berman helps set the stage for our response to one of the critiques by Professor Chin, who helpfully does focus attention on one of our policy assessments regarding intrafamilial testimonial privileges. Before we engage that specific disagreement, however, Professor Chin raises a larger challenge: namely, he asks that we specify more clearly which of our policy conclusions would be better analyzed with more empirical information, and which ones are impervious to more data gathering. For instance, he writes:

What are courts to do if data could be generated to resolve a particular issue, but has not, or if data is unreliable or uncertain? For two reasons, it is insufficient to say that these questions should simply be answered through research. First, lack of determinate data does not let judges off the hook; judges must either consider, or not consider, family status in setting bail in every single bail decision. However, the theory could provide that governments should be required to generate the data on this . . . as quickly as possible, so that going forward, decisions would be made on the correct basis. ${ }^{23}$

In advancing this possibility, Professor Chin correctly reminds readers that getting empirical information is not costless and that justice should be "dole[d] out as the best available approximation rather than as an exact quantity" ${ }^{24}$ - so we should be careful before anyone insists that the government perform empirical studies of every this and that.

But as should be clear by now (if it wasn't already clear in the book), ${ }^{25}$ the methodological strategy of the book was to erect normative speed

\footnotetext{
23. Chin, supra note 3, at 144 .

24. Id.

25. See Markel, Collins, \& Leib, supra note 4, at I5O ("We are open to being proven wrong through credible empirical evidence that would show that the benefits or burdens are
} 
bumps to get judges and policymakers to think about why family status as a trigger for exemptions or liabilities, subsidies or taxes, within the criminal justice system might be troubling. Empirical evidence may show that they are, after all, needed because they prove valuable or necessary to achieve a compelling or substantial interest. Of course, a judge faced with applying a law that uses family status as a benefit or burden may not see herself as free to ignore the legislature; but in exercising the judge's discretion (say, within sentencing or statutory interpretation), we think our considerations certainly have some force.

Still, our primary audience for our recommendations was not the judges simply required to follow laws but those who make them, whether through common law development or through legislation, ordinance, or administrative regulation. We cannot force those people to do empirical analyses, and we know doing it well can be costly and complex. But without much already available to us on the empirical side before we began, our book at least furnishes a starting point for policymakers to consider the various normative costs and consequences involved in the criminal justice policies under analysis.

Professor Chin wishes we had been clearer about when we thought we saw a trump card that would render our prescriptions impervious to empirical challenge. In short, he sees three types of policy analysis: (I) when the commitment to principle renders almost all empirical analysis irrelevant, (2) when empirical analysis determines the right policy result, and (3) when a range of policy outcomes are plausibly consistent with principles and knowable facts. ${ }^{26}$ Perhaps it is possible to divide the world of our policy recommendations into these three categories, and Professor Chin is certainly right that we didn't use these categories to summarize our book's contents. Unfortunately, when we wrote the book, we hadn't had the benefit of Professor Chin's typology to make clear when a policy prescription fell into one of the categories he specifies.

It is true that we think certain choices within criminal justice policy are likely to be immune from empirical contestation. For example, our

necessary to achieve some compelling state goal that cannot be achieved through less discriminatory means. At the very least, we hope our evaluation of the benefits and burdens defendants receive throughour the criminal law encourages other thinkers and policymak ers to develop more refined and systematic thinking about these pervasive practices.").

26. See Chin, supra note 3 , at 144 . 
commitment to nondiscrimination within the criminal justice system with respect to gays, single parents, and those with (or without) "nontraditional" families is quite strong, though we might divide amongst ourselves over how many Type I errors (mistaken convictions = false positives) or Type II errors (when the factually guilty go unpunished = false negatives) we would stomach to achieve equality in this respect. Nonetheless, the usefulness of the normative framework we develop in the book remains: policymakers will at least have a clearer sense of the various values at stake, some of which might be incommensurable.

Still, looking back at the book now, we don't think it would be hard to identify places when we argue that empirical evidence would be particularly useful to settle a question of whether a family status policy is a good idea and when we are pretty confident that our normative commitments produce conclusions that are virtually immune to empirical evidence. Indeed, when we were summarizing our conclusions in the Coda, ${ }^{27}$ we were clear that we remain open-minded to what better empirical evidence might show, but we expressed strong doubts that discriminatory treatment on the basis of status rather than caregiving function would ever be a narrowly tailored solution to further any compelling state interest.

Perhaps another way of answering Professor Chin's charge is simply to say that almost all our final conclusions fall into category (3) because they are all provisional, with one exception: if the criminal justice system is going to use benefits and burdens tied to caregiving responsibilities, it must not discriminate against gays, single parents, or other individuals in alternative caregiving arrangements. Such policies would fall into category (I), where we doubt empirical evidence is likely to sway us.

Even summarizing our ultimate conclusions this way, however, casts at least some doubt on the usefulness of Professor Chin's typology. After all, with some recommendations, we argued "in the alternative," i.e., if you don't extend to gays or others wrongly excluded, the burden/benefit must be rejected, but if you don't discriminate, you can adopt or retain $\mathrm{X}$ policy, assuming the empirical facts are as we suppose. That's what makes it hard to insert our recommendations cleanly into the categories Professor Chin provides.

Still, it is fair to generalize that many of our ultimate conclusions fall into category (3). As Professor Chin recognizes, the value of policy analysis

27. Markel, Collins, \& Leib, supra note 4 , at 150. 
in category (3) is to "highlight the costs, benefits, interests, values and other considerations that policymakers should use to choose from among reasonable alternatives. Policy analysis [within category (3)] can also identify the parameters beyond which policy would become unsound." ${ }^{28}$ That is what we hoped to do, for the most part. If we were successful there, the book performed its core function. As was clear to careful readers of the book, we could not always reach agreement on our prescriptions regarding the various laws under scrutiny in the book; surely we can't be surprised that we can't secure full agreement from readers.

Indeed, precisely for this reason, Professor Chin's effort to show why he disagrees with one of our provisional conclusions-that we should by and large abandon intrafamilial testimonial privileges-doesn't really shake the foundation of our book. To be sure, he makes some important points, undermining several admittedly weaker links in the chain of our arguments on that issue. ${ }^{29}$ But Professor Chin's specific thrust doesn't require too much of a parry. That we didn't capture every nuance under each of our normative guideposts only shows what we already know: policymakers will need to use our normative guideposts to consider different values and empirical foundations for judgment. That they might weigh accuracy more than equality in some cases is within the realm of reasonable disagreement.

Without more empirical evidence to answer some basic questions about what the likely effects of spousal privileges are, we can't say definitively what a perfect criminal justice system should do. Would the eradication of the privilege lead to more lying or to more accurate information? We think the latter, but we don't have the smoking gun study on that one, and

28. Chin, supra note 3 , at 145 .

29. Kudos to Professor Chin, in particular on his footnote 10. Still, it remains unclear why Professor Chin is so averse to establishing presumptions (as speed bumps) against legal rules when the etiology of a law is patently troublesome. If a state were currently living under laws established during and by a theocratic regime, and then, over time, the state tried to rectify many of its laws to eliminate discrimination against religious minorities, would it be so terrible to lodge skepticism toward those remaining laws, especially when those remaining laws, even though facially neutral, operate in a manner that disadvantages those religious minorities? To be clear, we weren't suggesting that the etiology, standing alone, was a reason to strike down a law that has already been modernized and "cleansed." Rather, we were making a narrower claim: that criminal laws that had once served the ends of patriarchy need to be examined to ensure that they no longer are drafted in such a way as to continue facilitating state-sanctioned subordination of women. 
we're uncertain how one would measuire that anyway. Perhaps Professor Chin's instincts on that issue differ-but we notice that he isn't waving such a study in our face, either. Our effort at coming up with a provisional conclusion was based on what we think we know and on the values we forthrightly admitted; thus it constitutes a first pass at applying our framework. The framework is more important than the ultimate evaluation, which we concede requires more information, when plausibly available and subject to assessment, and may require policymakers to prioritize among incommensurable values. As we've maintained: bring us a study and, if it holds up, we'll add it to the mix.

What we won't add to the mix, however, is Professor Chin's argument that the spousal privileges might be justifiable because the criminal law may be used to "reinforce community values." ${ }^{30}$ At least there, we do have a "category (I)" backstop: that the criminal law cannot be used to reinforce a discriminatory community value. If jurisdictions are not willing, for instance, to open up marriage to same-sex partners, we simply aren't willing to let a liberal state reinforce a discriminatory institution with the apparatus of the criminal law. But, of course, even if the state does open up marriage to gays and does nothing more, it still creates a world that places coupling ahead of individuals or noncoupled groups-a posture that stands, in the criminal justice context, in need of strong justification beyond "reinforcement of community values." So although Professor Chin's helpful critique is forthright about his desire to promote equality in marriage for gays, and thus fix some of the problems we identify, he does not think it's impermissible for the criminal justice system (or other aspects of the state) to distribute benefits (or burdens) that would operate to promote coupledom as against the interests of those who would remain single or polyamorous. Whether such policy design in the context of distributive justice is tolerable remains highly contested; it's something about which the three of us have substantial concerns. ${ }^{31}$ But it is precisely the criminal law's ability to reinforce community values so coercively that makes these

30. Id. at 148. Professor Chin himself won't have the criminal law reinforce community values that discriminate against gays. See id. at n.II.

31. For an excellent and lacerating overview of the extent to which our civil laws promote and privilege family status, see Ruthann Robson, Compulsory Matrimony, in Feminist and Queer Legal Theory: Intimate En'counters, Uncomfortable Conversations (Ashgate, 2009). 
discriminatory statements so dangerous, requiring us to be very careful about avoiding such statements altogether.

Indeed, it's partly for that reason that we must also protest Professor Chin's claim that liberal minimalism "is a device that will identify only nondebatable cases." 32 Professor Chin advances his point by reference to Professor Darryl Brown's discussion of how sodomy prohibitions were frequently thought justified by the harm principle. ${ }^{33}$ Unfortunately, we don't think this is enough to substantiate his claim against liberal minimalism. First, we don't equate liberal minimalism with the harm principle as such. Even if we had done so, that people might have made spurious arguments in the past under the guise of the harm principle (as in the examples furnished by Prof. Brown) doesn't mean that the harm principle or other limiting strategies have no capacity to police the boundaries of when it's permissible to invoke such a principle or limit.

More importantly, we used the modifier "liberal" prior to minimalism to convey two important meanings in our book. One had to do with the significance of being able to ascribe voluntariness to a person's action prior to criminal liability (through some germane exercise of autonomous choice), and the second had to do with ensuring the criminal law didn't trample on fundamental individual liberties. Thus, for example, if socially conservative legal moralists wanted to impose criminal law burdens on siblings or uncles or aunts by virtue of the "harms" such burdens were meant to prevent, our liberal minimalism would point out that this form of familial status is, on its own, an impermissible basis to create criminal liability, since no one "opts in" to such familial status. Maybe that seems like a "nondebatable" case, but consider: many people (including people who don't necessarily think of themselves as social conservatives, such as Professor Cahn) would reject our proposal to get rid of incest laws placing criminal prohibitions upon mature consensual sexual relations between adult siblings or aunts and uncles and their nephews or nieces. If that's the case, then liberal minimalism cannot be so easily dismissed as Professor Chin seems to suppose. ${ }^{34}$

32. See Chin, supra note 3, at n.r3.

33. See id. (quoting Darryl K. Brown, History's Challenge to Criminal Law Theory, 3 Crim. L. \& Phil. 271, 28I (2009)).

34. Professor Chin also argues that liberal minimalism should counsel in favor of keeping the parental discipline defense because excessive parental violence could be civilly regulated. Although we embrace the idea of "parental and pediatric education" to prevent spanking, 
Liberal minimalism, one might reasonably think, has implications beyond criminal law. But we didn't avoid analysis of the civil law and the institutions of distributive justice in the book just because of our comparative advantage as scholars of criminal law. Rather, we think criminal law has distinctive commitments and dangers that make it necessary to be especially concerned about discrimination on the basis of family status within its domain. ${ }^{35}$ That we leave open the possibility of legitimate reasons for civil legal institutions to consider family status doesn't render our analysis akin to a simple barter about price. ${ }^{36}$

We'll close this section of our reply by reference to one argument we wish to emphasize about the nature of empirical studies that overlaps in its relevance to answering both Professor Berman and Professor Chin. Although we've earlier alluded to the point here, we think it's worth reiteration that empirics only get you so far when analyzing the justifications underlying criminal laws. Consider the following examples:

- It shall be required of young brown-haired women to financially support older blond-haired women in their neighborhood if the blonds need the money; the failure to take adequate care of a needy older blond woman will render the younger well-off brown-haired woman eligible for criminal punishment.

- Jews will not be permitted or required to testify against each other in courts of law; the same goes for Presbyterians.

If states adopted rules like these, wouldn't it be worth setting out a preliminary set of reasons to think that these laws raise yellow or red flags? If states had rules like these permeating their legislative codes, we don't think, pace

one of the reasons public enforcement against parental violence (beyond a de minimis standard) is necessary is because there is no plausible private enforcement mechanism: children will be typically unable to bring suit against parents. Cf., e.g., Markel, Collins, \& Leib, supra note 4 at 104-05, 109, 113 .

35. We recognize that civil and criminal justice can blend at points: for example, violations of tax laws can often be enforced with the apparatus of criminal justice. However, when the criminal law gets involved, we think there are serious reasons to be concerned about an overly promiscuous use of criminal sanction (e.g., infringing on basic liberties) as well as an arbitrary use of such sanction (e.g., denigrating persons by virtue of status, not conduct).

36. See Chin, supra note 3, at text accompanying n.12. We note the possibility that civil law could promote "family life" that is repronormative without being inherently discriminatory toward gays and lesbians. 
Professor Berman, that it would be "problematically shallow or distorting" for criminal law professors to venture their considered views that these laws raise a number of troubling concerns based on what we know so far and could reasonably predict. It would be perfectly appropriate to note that these designations based on gender or religion or hair color are problematic in light of our aspirations for a just and safe legal order within a liberal democracy. The first rule, for instance, implicates concerns about arbitrary discrimination and unfair "takings" through the use of criminal law; the second raises similar concerns of arbitrary discrimination, and further presents a risk that the criminal justice system will face an increased level of Type I and Type II errors that jeopardize retribution and crime prevention-in the name of cultivating "fellow-feeling" among certain coreligionists."

If we asked people to do an analysis of such laws as drafted, we wouldn't judge them as having failed to dig deep simply because they weren't able to produce empirical evidence showing Type I or Type II errors. Nor would we think the endeavor is a failure because they didn't marshal empirical evidence of the crimes that weren't committed because the privilege between the coreligionists conduced to less crime, rather than more crime. Assuming the possibility of such a deterrent effect, it would be pretty hard to verify empirically the crimes that weren't committed as a result of the existence of these privileges. At best, we could see if jurisdictions with such evidentiary privileges had higher or lower crime rates, or perhaps we could see if a state that adopted such a privilege experienced a decline or rise in crime subsequent to its enactment or adoption. Thus, it might be true that "unless and until we have a deep understanding and full appreciation of the interplay of family connections and crime, any account or assessment of family-affected criminal laws will be shallow and potentially distorting." ${ }^{38}$ But if that's the standard by which all legal analysis is

37. Imagine two Jews and a Christian, Shimon, Levi, and Paul, respectively. Paul is, at TI, mistakenly convicted for a murder actually committed by Shimon. At T2, Shimon commits another murder, witnessed only by Levi, who also knows that Shimon committed the earlier murder and that Paul did not. The "proposed" rule prohibiting Jews from testifying against each other would mean that, if the prosecutors wanted to prosecute Shimon for the crime at $\mathrm{T}_{2}$, there would be increased risk of a false negative (i.e., Shimon escapes punishment); meanwhile Levi's inability to inculpate Shimon for both crimes makes it more difficult to prove to others that Paul is the victim of a mistaken conviction, i.e., the rule increases the risk of a Type I (false positive) error.

38. Berman, supra note $\mathrm{I}$, at 120 . 
judged, especially at the beginning of a research agenda, it would be an odd one to use. Or so we think.

\section{PROFESSOR BERMAN'S NAGGING FEELINGS ABOUT OUR "TRUE" GOALS}

The second part of Professor Berman's review raises a cluster of disparate inquiries.

\section{A. What Kind of Criminogenesis Matters?}

First, Professor Berman argues that we're less interested in the criminal justice system and its distinctive values than we are in the "construction and norms of family status in modern society." ${ }^{39}$ Professor Berman draws this inference about our "true project and motivation" and "true goals and commitments" by looking at Part II of our book, where, in the course of examining which factors should apply to the scrutiny of family ties burdens, we note that family ties burdens are less likely than family ties benefits to incentivize more crime directly or to disrupt the accurate prosecution of the guilty or exoneration of the innocent. We are puzzled by Professor Berman's speculations that the interests we identify as relevant to the first half of the book (having to do with family ties benefits) are less sincerely considered than the ones we think relevant to Part II (having to do with family ties burdens).

Let's stipulate for the moment that the criminal justice system has a compelling interest in reducing and punishing the incidence of (at least) malum in se crimes. For reasons we elaborate in the book and that should be readily perceptible to readers of this Essay, it seems likely to us that intrafamilial evidentiary privileges or laws granting exemptions from prosecution for harboring family member fugitives are practices that create risks that will inhibit the just prosecution and punishment of persons engaged in malum in se crimes. By contrast, we expressed doubts that the family ties burdens we explore (e.g., criminal laws requiring adult children to pay for the costs of indigent elderly parents) will directly reduce Type I or Type II errors with respect to (malum in se) crimes. Of course, as we noted in

39. Id. at 123. 
the book, such laws obviously will create a new form of criminal liability for offenders who violate the laws creating family ties burdens, but that points to a different kind of criminogenesis concern than the one we were raising in Part $\mathrm{I}^{40}$

If Professor Berman's claim is that family ties burdens such as parental support laws or bigamy laws indirectly serve to reduce or punish the incidence of malum in se crimes, then, if true, that would be a problem for our claim that the family ties burdens typically do not raise issues associated with the goal of reducing Type I and II errors. But, contra Professor Berman, we do actually consider such arguments when they have been raised in defense of these family ties burdens, such as parental supervision laws." And if that's Professor Berman's argument, he has, again, adduced no evidence showing that states without such family ties burdens are suffering worse crime rates (especially with respect to malum in se crimes) than states with such family ties burdens.

\section{B. The Implications for Domestic Violence}

In the same vein, and again, quite curiously, Professor Berman suggests our "true goals" associated with "our general presumption" against the use of family status leads us away from discussing the laws of domestic violence more. ${ }^{42}$ Why, he asks, don't we address developments ranging from the "elimination of marital rape exceptions, to the invocation of uniquely severe sentences when parents rape or kill their children, to the creation of mandatory prosecution programs for domestic violence and mandatory reporting requirements for child abuse?" ${ }^{33}$ We can't quite espy the connection between these "true goals" and this selection of what we do and do not examine.

But more importantly, as we explain in the Coda, we do have explanations for why we don't address the domestic violence laws in great detail, notwithstanding our view that these laws are a significant and important aspect of our fight against the scourge of domestic violence.

40. This was the significance of the point we made in the footnote Professor Berman references. Markel, Collins, \& Leib, supra note 4, at 199-200 n.9.

41. E.g., id., at II2-18 (discussing deterrence evidence and arguments associated with parental supervision laws).

42. Berman, supra note I, at II9.

43. Id. at 124 . 
As an initial matter, our studies revealed no obvious and consistent pattern to whether domestic violence laws across the states operate as either benefits or burdens. For example, the states continuing to accord some preferential treatment to perpetrators of marital rape could be characterized as conferring a benefit to a defendant based on his family status, ${ }^{44}$ whereas a law mandating arrest in cases of domestic assault, but not stranger assault, could be characterized as a burden, assuming the "shall-arrest" law was triggered by legal family status, rather than just coresidence or intimate association. In other words, there is diversity regarding whether one's family status triggers an enhancement or a mitigation of punishment in the domestic violence context.

Moreover, the book developed two significant claims relevant to the design of domestic violence policy. First, although much work to improve the situation has already been done in this regard in recent years, to the extent a domestic violence law is written in terms of traditional family status, we urged shifting the focus to circumstances and function, not legal family status. ${ }^{45}$ (Co-residence or intimate association would be helpful factors to look at; the production of a marriage certificate, by contrast, should not be a necessary condition to serve as an element that triggers the intended protections.) Thus, needless to say, an individual victim should not be denied the protection of a state statute on restraining orders because she is in a same-sex relationship rather a heterosexual one. Second, if jurisdictions decide to impose burdens based on functional categories such as voluntarily assumed caregiving relationships, then we think it is justifiable (from the standpoint of our normative framework) to impose additional burdens (in terms of liability or punishment enhancements) because of the moral wrong associated with a caregiver abusing the trust owed to the recipient of care. We described this in the book as a separate wrong involving an abuse of trust that affects the public because the person who breaches a voluntarily entered caregiving relationship (e.g., a spouse or parent) has engaged in a form of "sequestering" and "lulling" of the sort that is analogous to the kind of duty that has traditionally triggered omissions liability at common law.

44. See Markel, Collins, \& Leib, supra note 4, at II.

45. Of course, to the extent many states have drafted domestic violence laws in terms neutral to family status, they generally fall ourside our designated focus of atrention. As we said earlier, our decision not to examine them in depth obviously does not deny their significance to the criminal justice system as a whole. 


\section{Why Family Status Ought to Be Largely Irrelevant to Criminal Liability}

In further service to his thesis about our "true goals," Professor Berman also challenges the analogy we make between religious affiliation or ethnic background on the one hand and the family status of the defendant on the other. ${ }^{46}$ As we emphasize at different points, our view does not deny the psychological or moral importance of bearing the responsibilities and role of parent, sibling, daughter, and so forth. ${ }^{47}$ Rather, we challenge the moral significance that family status ought to play in the distribution of benefits or burdens within the criminal justice system when we are able instead to focus on more clearly delineated functions. In that respect, we reiterate our point that family status is morally irrelevant to the determination of liability and punishment, just as one's religious affiliation or ethnic background is in the absence of other relevant information.

To elaborate a bit more, we think it's worth examining Professor Berman's three specific contextual challenges on this point. First, regarding the issue of whether parents who rape or kill their children should be exposed to higher sentences, ${ }^{48}$ we already mentioned how our Coda in fact addresses this question directly, arguing that this scenario usually permits a finding of a separate abuse of trust that occurs in that situation, and thus, that such a wrong permits increased punishment. ${ }^{49}$ Of course, on our account, the application of the enhancement should not turn simply on whether the defendant is a parent or the victim is a minor child; rather the inquiry should be focused on whether the defendant can be said to have voluntarily undertaken a relationship of caregiving to a victim who can be said to be especially vulnerable to exploitation through that trust relationship, and whether such a trust relationship could be understood by the public to exist. That focus would encompass consideration of a range of factors beyond just bloodlines or legally recognized status relationships. So the voluntarily assumed caregiving relationship is the morally significant point upon which benefits and burdens ought to turn. The label of brother, mother, or uncle does little work alone.

46. Interestingly, some other critics of the book try to gain traction by stressing the analogy between family status and religious affiliation. See Alice Ristroph \& Melissa Murray, Disestablishing the Family, Yale L.J. (forthcoming 2010).

47. Markel, Collins \& Leib, supra note 4, at 180 n. 62.

48. See Berman, supra note I, at I24.

49. See Markel, Collins, \& Leib, supra note 4, at I53. 
This focus on function and circumstance, not family status, influences the outcomes in the other two cases Professor Berman proposes as tests: (a) a "mother's decision to 'kidnap' her own son from an abusive ex-husband and kidnapping someone else's child," and (b) a "modern-day Jean Valjean stealing bread to feed his own family and stealing bread to give to a soup kitchen." 50

In the former situation, the defendant mother might be able to prove an affirmative defense (resulting from fear that the child will be endangered by the abusive parent); in other words, the status of the kidnapper as parent does not, in our view, legitimize the desire for leniency or no liability - it is the plausibility of the justification (or excuse) operating for the defendant. In the second hypothetical, we might wonder whether Valjean has better information (than a stranger) regarding imminent danger to the family, and that is what motivates the theft; if true, he too might be a suitable claimant for an affirmative defense.

Importantly, it is not, in our view, Valjean's standing as caregiver as such that would negate liability or warrant reduced punishment. Indeed, if circumstances were such that an indigent neighbor knew of Valjean's family's imminent starvation, we would want the indigent neighbor to be able to benefit from an affirmative defense; we don't see why one would limit the availability of the defense only to someone who stood in a legally recognized relationship to those within the Valjean family. Well, actually, we do see why-it is easy to use simple categories that the law has drawn on in the past for administrative ease, based on historical moral blind spots. But we spent great effort in the book trying to convince readers that administrative ease or uncritical embraces of tradition are no excuse for reflexively choosing status over factors like function and consent when it comes to matters as serious as criminal justice.

\section{PROFESSOR CAHN}

Professor Naomi Cahn adds some welçome historical and cultural texture to some of the issues regarding voluntariness, incest, and domestic violence that we discuss in our book. That said, we're not persuaded about the specific challenges to us that she advances.

5o. Berman, supra note I, at I25. Note that Professor Berman's hypothetical gives us no reason to think a person kidnapping someone else's child will be saving that child from abuse. 


\section{A. Voluntariness and Motherhood}

Professor Cahn begins her essay by discussing the voluntary nature of family relationships, which we cite as an important consideration when evaluating whether a particular family ties burden is justified, and suggests that our account of voluntariness in the parent-child and spouse-spouse contexts is "highly problematic and insufficiently thick." ${ }^{\text {II }}$ Although she briefly mentions that voluntariness is hard to locate in the spousal context when there is domestic violence, she then focuses her discussion here entirely on the parent-child relationship and suggests that "poor women are least likely to use birth control and most likely to experience unplanned pregnancies, and so to call their parenthood 'voluntary' distorts their relationship with their children." 52

As we acknowledged in the book, there are some "complications with this general observation of voluntariness" in the context of parent-child relationships. ${ }^{53}$ We are grateful to Professor Cahn for fleshing out the important role that poverty can play in influencing an individual's decisionmaking regarding procreation. ${ }^{54}$

Nonetheless, even though it is true that poverty may affect a woman's choices regarding procreation, we do not think that undermines our arguments. First, as long as individuals freely choose to engage in sexual conduct, and as long as the state continues to give individuals the option to terminate their parental responsibilities (e.g., by placing their children up for adoption), we believe it is appropriate to characterize the obligations that arise from the status of parenthood as voluntarily assumed, even

5I. Naomi Cahn, Protect and Preserve? I3(I) New Crim. L. Rev. 127, 129 (2010).

52. Id. at I30. For what it's worth, just as we acknowledge many of the difficulties associated with assuming voluntariness in the parental relationship under certain circumstances, our book also addresses the challenges to voluntariness that might erupt in the spousal context. See, e.g., Markel, Collins, \& Leib, supra note 4, at 87-88. We specifically identified human trafficking victims forced into marriage as an example where voluntarism can easily be rebutted, but we concede that premarital domestic violence might also, in certain circumstances, be sufficient to rebut the ascription of voluntariness in the spousal context too.

53. Markel, Collins, \& Leib, supra note 4 , at 88 .

54. And we recognize that various civil laws provide strong incentives for marriage and procreation. See generally Robson, supra note 31. That said, we don't think the array of social influences and legal and economic incentives, as such, amount to coercion or compulsion in any form recognizable to ordinary linguistic or legal usage. 
if the choice to retain parental rights is an emotionally or financially diffcult one.

Importantly, even if parenthood under such circumstances were deemed involuntary, there is the significant question about how the law should judge the relative capacities and vulnerabilities of poor mothers vis-à-vis their children. If a woman becomes a mother in part because no subsidized forms of birth control are available, the administrators of Medicaid refused to pay for her abortion, and no abortion providers are willing to work pro bono, ${ }^{55}$ would Professor Cahn really be willing to suggest that this poor woman should be relieved from the responsibility to protect her infant from imminent peril if she could do so at no risk to herself? In that situation, we think ensuring the safety of a child "remains the most fundamental of reasonable burdens," ${ }^{56}$ at least until she hands the child over to the state or some other private party who would assume the responsibility of care. Don't get us wrong. Our society surely needs to do more to improve access for poor women to health care generally, and to contraception and abortion in particular. But those class-based problems don't seem to us to be sufficient to relieve parents of a duty to perform costless rescues-a duty we think is voluntarily assumed given the available (though no doubt difficult and emotionally fraught) "avoidance" options of forbearing from sex, using contraception, abortion, or terminating one's parental rights.

\section{B. Incest (among Adults)}

Although Professor Cahn agrees with our views on most of the family ties burdens, she wants to challenge our views of incest. We think her principal disagreement with us here centers on whether incest bans should prohibit relationships between individuals who were once in a relationship of asymmetrical dependency-meaning parents and children, in all forms that relationship can take, including step-parenting and foster parenting-even after the children reach adulthood. For example, she argues that "it remains critical to recognize the uniqueness of the breach of trust between family members

55. See Cahn, supra note 5I, at I3I (describing how many poor women who want to have abortions cannot obtain them because Medicaid funding may generally not be used to fund abortions absent rape, incest, or endangerment to the life of the mother.)

56. Markel, Collins, \& Leib, supra note 4 , at 100. 
that occurs if these family members engage in sexual relationships, even when the family members are adults." ${ }^{57}$

Professor Cahn's essay affords us the chance to reiterate our position on this issue. Two of the three authors (Collins and Leib) fully agree "that persons who once had a relation of asymmetric dependence should be precluded from future relations," even when the parties are both adults, because of precisely the concerns that Professor Cahn identifies. ${ }^{58}$ Professor Markel, on the other hand, believes that even these individuals may be able to form a relationship based on genuine and mature consent, assuming the parties were willing to take measures to signify that genuine and mature consent before others. ${ }^{59}$

To the extent that Professor Cahn is suggesting that the criminal law should be used to prohibit all relationships between adults of different generations, even when all the parties are mature adults, the three authors are of one mind on this issue-i.e, that a blanket prohibition via criminal law is improper. Imagine an uncle and niece, who meet for the first time when the niece is thirty-five years old and the uncle fifty-five. If the parties are truly capable of genuine and mature consent, we do not believe that the criminal justice system, with its threat of coercive stigma and/or incarceration, should be utilized to infringe upon their intimate associational rights in the absence of any showing of coercion. The state remains free to use mechanisms of civil justice, for example by denying marriage licenses, and the powerful weapon of social stigma to signal its disapproval of such relationships; we take no position on that issue.

\section{Domestic Violence}

Finally, Professor Cahn turns to the issue of domestic violence and illustrates the seriousness of the problem and the long neglect of this issue by the criminal justice system. We largely agree with her descriptive characterizations of the problem. Moreover, as mentioned earlier, we think there is a basis for enhanced penalties in the context of crimes against those under one's voluntary care based on an abuse of trust theory. ${ }^{60}$ Professor Cahn

57. Cahn, supra note 5I, at 136.

58. Markel, Collins, \& Leib, supra note 4 , at 211 n.70.

59. Id. at I2I; 2 II nn.70, 72, 74.

6o. Markel, Collins, \& Leib, supra note 4 , at I52-\$3. 
appears to agree, arguing that "some crimes really are different because of the abuse of trust," ${ }^{61}$ and as we plainly indicated above and in the Coda to the book, we concur. ${ }^{62}$ As we wrote and elaborated earlier, "breaking a covenant of care by inflicting injury [with mens rea] is thus a greater moral wrong than inflicting an injury on an individual to whom such a specific covenant of care is not owed . . ." ${ }^{63}$ But as we also emphasized, the abuse of trust theory supporting an enhancement would not be restricted to family members. We could imagine a range of people outside the spouse or parent context who might also warrant increased punishment based on voluntary assumptions of supervisory or custodial care.

Moreover, toward her conclusion, Professor Cahn endorses the controversial claim that victims should be able to dictate or control the criminal justice outcomes associated with domestic violence cases. ${ }^{64}$ Whereas we may disagree (amongst ourselves) to varying degrees with the substance of the claim that victims should be given outcome-determinative influence on domestic violence as well as other crimes, we will prescind from extensive comment on Professor Cahn's apparent prescription. After all, to the extent modern domestic violence statutes in American jurisdictions do not turn on family status, but instead focus on co-residence and/or intimate association, we don't think our framework has anything unusually special to say regarding how to strike the balance between victims and prosecutors in this delicate context. ${ }^{65}$ That's why we thought this issue was beyond the scope of our book, a conclusion Professor Cahn notes.

6I. Cahn, supra note 4I, at 139.

62. Professor Cahn argues, however, without citation, that the "the book alleges that the law seems to assume domestic violence is worse than other kinds of violence," Cahn, supra note $4 \mathrm{I}$, at 137 . Professor Cahn misreads us here; the book recognizes that there is a diversity of approaches under past and current law regarding whether domestic violence is more condemnable than "nondomestic" violence. See Markel, Collins, \& Leib, supra note 4, at $15 \mathrm{I}$ (noting that states have taken "wildly inconsistent" positions regarding domestic violence laws). Our normative approach, however, explains why we think domestic violence involving an abuse of power or trust warrants enhanced penalties.

63. Id. at 153 .

64. Cahn, supra note 4I, at I4I ("We might seek to develop new policies that allow victims control over choices in the criminal justice and mediation system because of their family ties.").

65. We do commend to readers, however, that they consider the tensions identified by Jeanne Suk in her recent book, At Home in the Law: How the Domestic Violence Revolution Is Transforming Privacy (2009). 
Unfortunately, Professor Cahn mistakenly thinks that, merely because we acknowledge this tension between victim autonomy and prosecutorial obligation, we are somehow committed to recognizing the need for special treatment for family ties. ${ }^{66}$ Here, we disagree on two grounds. First, as mentioned above, the challenges posed by these laws to victims' autonomy arise in the domestic violence context regardless of whether the victim was related to the perpetrator. Second, and more importantly, the tension between recognizing the desires of victims and the desires of the prosecutors or public is a tension that, contra Professor Cahn, has long transcended the domestic violence context. ${ }^{67}$

\section{CONCLUSION}

It is always rewarding to have an opportunity to reply to critics-especially distinguished ones who have taken the trouble to ask the hard questions. We reiterate our gratitude to them for engaging our work and giving us food for thought as we stand back and look at the product of our years of work together. We hope that this Essay captured a few useful observations and addressed some of our critics' largest concerns.

66. Cahn, supra note 4I, at 137 ("'Domestic violence should, however, be treated differently from other violent crimes not involving family members.' Indeed, one of the 'important questions that are beyond the scope of [the book's] limited efforts' is how 'criminalization may itself be threatening to women's autonomy' (153). Surely this is not a question that would be asked about other violent crimes; we would not suggest that criminalizing violence 'may itself be threatening to [the victim's] autonomy.' Yet, given the nature of domestic violence, this is a legitimate inquiry. Obviously, domestic violence presents a complex set of issues with respect to criminalization within the family.").

67. Indeed, this well-trod territory over the rights and roles of victims (across all crimes, not just ones involving domestic violence) has long been an obsession for theorists ranging from retributivists to restorative justice proponents, among others. See generally Markus Dubber, Victims in the War on Crime: The Use and Abuse of Victims' Rights (2002); George P. Fletcher, The Place of Victims in the Theory of Retribution, 3 Buff. Crim. L. Rev. SI (1999); Michael S. Moore, Victims and Retribution: A Reply to Professor Fletcher, 3 Buff. Crim. L. Rev. 65 (1999); and Douglas E. Beloof, Paul G. Cassell, \& Steven J. Twist, Victims in Criminal Procedure (2nd ed. 2005). 